\title{
Contextuality and Intercontextuality in Public Theology: On the Structure of Churches' Public Engagement in South Africa and Germany
}

\author{
Willem Fourie $^{1}$ and Hendrik Meyer-Magister ${ }^{2}$ \\ ${ }^{1}$ University of Pretoria, South Africa. (willem.fourie@up.ac.za) \\ ${ }^{2}$ Humboldt-University Berlin, Germany. (Hendrik.Meyer-Magister@evtheol.uni-muenchen.de)
}

\begin{abstract}
Contextuality and intercontextuality remain important themes in the burgeoning field of public theology. The authors employ a comparative and descriptive approach to contribute to this complex of themes. It is done by investigating and comparing the concrete ways in which churches in South Africa and Germany structure their public engagement. The authors find both significant similarities and differences and conclude with two consequences for reflection on contextuality and intercontextuality in the field of public theology.
\end{abstract}

Keywords: Germany; South Africa; contextuality; public theology; politics

\section{Contextuality}

In 2011 the Global Network for Public Theology hosted a conference on the theme "Contextuality and Intercontextuality in Public Theology" at the University of Bamberg in Germany. The conference was aimed at analysing "contextuality and at the same time investigate where the common features of all contextual public theologies can be found". ${ }^{1}$ In addition to the publication of the conference proceedings in $2013,{ }^{2}$ the theme of contextuality in public theology has continued to be a topic of investigation, albeit from a wide array of perspectives. Two recent issues of the International Journal of Public Theology, for example, were devoted to public theologies in specific contexts, namely in South Africa ${ }^{3}$ and Brazil. ${ }^{4}$ In their articles Dominic O'Sullivan ${ }^{5}$ and Jayakiran Sebastian ${ }^{6}$ investigate the contextual interpretations and enacting of, respectively, reconciliation and multiculturalism from broadly public theological perspectives. Mark Toulouse ${ }^{7}$ investigates the increasing privatisation of religion in Canada, which he compares to selected dimensions of religion and public life in the United States of America.

In this article we aim to contribute to the ongoing discourse on contextuality and intercontextuality in public theology. Like Toulouse, we employ a comparative approach, but quite unlike his and the other cited projects, we investigate the concrete ways in which churches structure their public engagement. We focus on the structures of churches' public engagement in Germany and South Africa by employing a descriptive, empirical and inductive perspective. The contribution of this article therefore lies on two levels. We seek to make a comparative and decidedly descriptive contribution to the field of public 
theology. On a second level we seek to expand knowledge on the structures of public engagement in Germany and South Africa. We regard comparison as a potentially intercontextual endeavour, as it includes the promise of transcending contextual particularities.

It is not uncommon to compare the public role of churches in South Africa with those in Germany. This is especially true for comparisons between Reformed churches in South Africa and the country's twenty Lutheran, Reformed and Unitarian churches and their representative body, the Evangelische Kirche in Deutschland (ekd) [Protestant Church in Germany]. It is also not surprising that comparisons are made, as there are numerous points of connection between churches in South Africa and Germany. Theologically, the influence of the Reformation and Reformers such as Martin Luther and John Calvin connect many churches in the two countries. It is also relatively easy to find points of connection between their recent political histories. The totalitarian and racist political system of apartheid is often compared with the totalitarian and racist elements of the Deutsches Reich [German Reich] from 1933 to 1945 . Both countries also relatively recently experienced processes of fundamental political change and the subsequent challenge of reintegrating different groups of people. In this regard reintegrating the German Democratic Republic and the Federal Republic of Germany in the late 1980s is often compared with the post-apartheid project of unifying the Rainbow Nation.

In South Africa and in Germany churches were in different ways entangled with their respective political systems, a point which is often used as a further point of reference for finding similarities between the two countries. Certain South African churches, notably the Dutch Reformed Church, were closely aligned to the National Party, which eventually took power and instituted apartheid. Also the Deutsche Christen [German Christians] supported the increasingly racist and totalitarian political program of Adolf Hitler's

Nationalsozialistische Deutsche Arbeiterpartei [National Socialist German Workers' Party, or simply the Nazi Party]. Other South African churches, notably the Dutch Reformed Mission Church (which eventually united with the Dutch Reformed Church in Africa in 1994 to form the Uniting Reformed Church in Southern Africa, or urcsa) actively fought against apartheid, just as the Bekennende Kirche [Confessing Church] resisted the Nazi regime. Parallels are often drawn between URCSA's Belhar Confession and the Bekennende Kirche's Barmen Declaration, both confessional documents drawn up in the midst of the struggle against unjust political regimes.

Strong institutional ties between churches in Germany and South Africa, as well as between centres of theological education and research, continue up to this day. The burgeoning field of public theology is a case in point. Close collaboration between scholars from South Africa and Germany on issues related to the public role of churches in their respective contexts partly characterise the Global Network for Public Theology and numerous publications in the International Journal of Public Theology and South African theological journals such as the Dutch Reformed Theological Journal, Verbum et Ecclesia and hts Theological Studies. This very article is the result of close institutional ties between the Humboldt University in Berlin, Stellenbosch University and the University of Pretoria. 
In the following section we provide working definitions of the concepts "church" and "public". Based on these working definitions we then map the ways in which churches in South Africa and Germany structure their public engagement. We conclude with a reflection on the implications of key similarities and differences.

\section{Concepts}

In accordance with our comparative approach, we base our working definitions of, and the connections between, the concepts of "church" and "public" on the work of, and connections between, a prominent German public theologian and public intellectual, Wolfgang Huber, and a South African systematic and public theologian, Dirk Smit. Both theologians have reflected extensively on the concepts of "church" and "public", at times drawing on a similar corpus of sources and even on one another's work.

\section{Church}

Huber and Smit stay close to the classic distinction in Protestant ecclesiology between the congregation of saints and the social form of the church. This distinction is expressed in the confessions that developed during the Reformation. While the congregation of saints embraces all true Christian believers and forms the body of Christ in this world, the external society of the church is a mixed body of believers and others. Or, in the words of the Augsburg Confession: the church "properly is the congregation of saints and true believers", even though "in this life many hypocrites and evil persons are mingled therewith". ${ }^{8}$

In an extension of classic Protestant views, Huber expands on this distinction. In his early work he uses the term wirkliche Kirche [actual church] to describe the ambiguity of the historical existence of the church. ${ }^{9}$ In other works, such as Folgen christlicher Freiheit [Consequences of Christian freedom] (1983), he describes the actual church as "the place where the battle between the true and the false church takes place; the place therefore where the battle to either correspond to the true church or to contradict it always starts again". ${ }^{10}$ Smit, in an article published in 1996, ${ }^{11}$ similarly emphasises the existence of an "actual" church when he argues that "the Christian community of faith is not simply the religious variant of natural groups, movements, social strata and so forth", but that the church is unique because of the "shared faith in Christ" that "makes Christians part of the church, the body of Christ". ${ }^{12}$

Huber regards the wirkliche Kirche as a reminder of the relevance of the historical form of existence of the church. It is not possible to speak of the "social form of the church" without also speaking of its nature, as it is not possible to speak of the "experienced church" without speaking of the "church of faith". ${ }^{13}$ Based on the work done by Huber and Smit, and acknowledging the indissoluble link between the social form and the nature of the church, we focus our use of the concept of "church" for the sake of this article on the experienced, visible, social and institutionalised forms in which the true church of believers becomes publicly apparent in German and South African society. 
When speaking of the experienced church, or the forms in which the true church exists in concrete societies, Huber distinguishes between the church as Ortsgemeinde [local congregation], Initiativgruppe [initiative group], Regionalkirche [regional church] and Föderation [federation]. ${ }^{14}$ Smit expands on these distinctions and identifies six forms in which the church exists, namely as worshipping communities, local congregations, denominations, ecumenical bodies, voluntary organisations and individual believers. Taken together, the distinctions provided by Huber and Smit can be integrated into a matrix with four elements to classify the different structures of public engagement: tradition of confession, or denomination; organisational form, such as federation; shared aims that go beyond the confessional tradition, or forms of ecumenical association; and the geographical scope, such as regional churches. This means that it is possible to typify the empirical structures of the experienced church as, for example, denominational regional churches, or federal denominational churches, or ecumenical regional churches.

\section{Public}

In their early reflection on the possible meanings of "public", both Huber and Smit engage the work of Jürgen Habermas which he first presented in his book Strukturwandel der Öffentlichkeit [The Structural Transformation of the Public Sphere] in $1962 .{ }^{15}$ Already in his Master's thesis Smit "[dealt] extensively with Habermas's analysis of the public sphere". ${ }^{16}$ At more or less the same time Huber engaged with Habermas in his book Kirche und Öffentlichkeit [Church and Public]. ${ }^{17}$ Despite the influence of Habermas's thought on both Huber and Smit, neither of them views his influence as definitive for their understanding of the concept of "public". It is thus not surprising that in the work of Huber and Smit differences in their respective concepts of the public also become explicit. According to Smit, it is possible to argue that Huber is in fact not in the Hambermassian tradition. In a relatively recent article Smit distinguishes between three understandings of the meaning of "public" in theology, and he discusses Habermas and Huber as representatives of two different schools of thought, with David Tracy as representative of a third. Smit views Habermas's understanding as "fairly technical and normative". ${ }^{18}$ "Public", according to Smit's characterisation of Habermas, refers to "the sphere, often represented by specific public spaces and practices, where an informed public opinion is formed and maintained, able to resist the powers of politics and market, and characterized by critical discussion between equal participants, free of constraint, threat and self-interest" ${ }^{19}$ According to Smit, Huber represents a different school of thought, based "on the insight that gospel, church and theology have always been concerned with public life in the ... sense of life in general or life in the world. ${ }^{20}$ Smit views this as the sense in which "public" is used most often, also without the theological content Huber attaches to it. When applied to the role of the church, this understanding of "public" addresses three themes: "the place of the church in public life, the social form of the church and the role of the church in society". ${ }^{21}$ Tracy, according to Smit, represents a third school of thought which holds that "all theological discourse is public in the sense that it addresses specific audiences or publics". ${ }^{22}$

In terms of Smit's categorisation, our working definition of "public" broadly fits into Huber's school of thought. In an instructive and influential article "Öffentliche Kirche in pluralen Öffentlichkeiten" [Public church in plural publics] published in $1994,{ }^{23}$ Huber elaborated further on his early concept. It is also here that Huber first proposed the concept of a 
"public church". ${ }^{24}$ For Huber, the engagement of the public church refers to four societal spheres, namely the state, the economy, civil society and the cultural communication within a given society. ${ }^{25}$ Even though the church mainly belongs to the sphere of cultural

communication, the public mandate of the church is applicable to all four societal spheres. ${ }^{26}$ Because of the limited space of this article we focus on the political dimensions of the "public". Accordingly, we focus on the current structural relations of the church and the political system, in a narrow sense, in Germany and South Africa. However, our approach is not intended to disregard the other dimensions. To deal with them-e.g. the massive economic entanglement of the church with society as employer, or the role the churches play in the civil society public as service provider in the field of social welfare-would go beyond the limited scope of this article.

When our working definition of the church is viewed in the context of our rather descriptive understanding of a political "public" the church can be described as a societal association. ${ }^{27}$ More specifically, and in agreement with Huber, the church in constitutional democracies can be viewed as a collection of "attitude groups". ${ }^{28}$ This also corresponds with the views of the German political scientist, Ulrich Willems, who is of the opinion that "much can be said for regarding churches, in view of their participation in political processes, as interest groups (in the broader sense)" ${ }^{29}$ Which interests do they actually represent? Willems argues that, apart from the self-interest of the church concerning its own position in the social structure, it aims to communicate and enforce its value orientations as well as moral claims concerning the individual and shared form of living. ${ }^{30}$ In this article our interest lies with the identifiable structures and channels through which the churches communicate their interests and ethical orientations as well as their claims within the political system.

\section{Structures}

\section{Structure of Denominational Affiliation}

It is safe to say that Christianity is the dominant religion in both South Africa and Germany. According to the latest available official statistics, nearly $80 \%$ of South Africans describe themselves as Christians. ${ }^{31}$ About $16 \%$ of South Africans choose not to describe themselves in terms of any religious affiliation, and the remainder belong to other religions. Islam is the second-largest religion in the country, with about $1,5 \%$ of South Africans who describe themselves as adherents. Even though these statistics are from Statistics South Africa's 2001 Census, $^{32}$ there is little evidence that major shifts in religious affiliation have taken place in the last decade. ${ }^{33}$ In Germany, according to the data of a census from $2011^{34}$ and data from the Evangelische Kirche in Deutschland [Protestant Church in Germany] (ekd), ${ }^{35}$ more than $60 \%$ of Germans are members of a church. A comparatively large number of Germansmore than $30 \%$ - are unaffiliated with any religion. Muslims form the next biggest religious group in Germany with a share of $4,89 \%$. Jews, Hindus and Buddhist together amount only to less than $1 \%$ of the population.

With regard to the number and religious attitudes of Christians in Germany, a key debate concerns the interpretation of the perceived decrease in church members during the past few decades. ${ }^{36}$ The ekd is a case in point. Between 2002 and 2012 the churches in the ekd 
have suffered an absolute loss of nearly three million members. During the same time the absolute number of Christians in Germany decreased from $65,7 \%$ to $62 \%$. This seemingly dramatic decrease, however, cannot be interpreted adequately without taking the demographic transition in Germany into account. In the same decade the German population shrank by just more than two million people, or $2,2 \% .{ }^{37}$ It is interesting to note that the affiliation to the churches in the ekd have decreased by almost the same percentage-namely $2.7 \%$-as the general German population. There is indeed a notable correlation between the demographic development and the loss of members of the ekd. ${ }^{38} \mathrm{~A}$ further interesting observation is that in recent years baptisms, re-entries and conversions have outnumbered the total number of departures from the ekd. Despite all scenarios of decline, the German church seems astonishingly stable in terms of membership.

Major differences emerge when one examines the denominational adherence of Christians in Germany and South Africa. In Germany the vast majority of Christians belong either to the Roman Catholic Church (about 50\%) and churches in the ekd (also about 50\%). The Roman Catholic Church and the Protestant churches organised in the ekd can be called the German mainline denominations. While the German Roman Catholic Church as part of the global Roman Catholic Church is clearly a denominational church, things are different with the ekd. According to its church order, the ekd is "a community of Lutheran, Reformed and Unitarian member churches". ${ }^{39}$ The ekd is therefore, in a strict sense, a federal church of twenty Lutheran, Reformed and Unitarian regional churches, the so-called Landeskirchen. These regional Landeskirchen keep their denominational status according to their Lutheran, Reformed or Unitarian confessional traditions. Nonetheless, the members of the ekd grant each other full church community, in accordance with the Leuenberger Konkordie [Leuenberg Agreement]. ${ }^{40}$ This is why, despite its internally varying denominational status, theologically the ekd can be identified as a federal but still denominational church. ${ }^{41}$ The German mainline churches enjoy, on the one hand, certain privileges granted by the state and, on the other hand, cooperate with the state to fulfil certain societal tasks. These relations are based in the German constitution and specified in so-called Staatskirchenverträgen-contracts between the German federal states and the regional Landeskirchen. ${ }^{42}$

Apart from the two mainline churches, the orthodox churches form the third biggest Christian group in Germany, with about $2 \%$ of the German Christians as members. Only very few German Christians, less than 1\%, belong to the so-called Freikirchen [free churches], which are also often, just like the mainline churches and other religious communities, organisations according to public law, but refrain from accepting any public privileges to maintain a greater distance from the state. ${ }^{43}$

In comparison to Germany, Christians in South Africa belong to a dizzying array of churches. For the sake of clarity we categorise their religious affiliation into three groups. Roughly $40 \%$ of all Christians, the first group, belong to nine mainline denominations. The Methodist Church of Southern Africa, Roman Catholic Church and Reformed churches, each with about $9 \%$, are the largest groups of denominations. It should be added that there are a number of Reformed churches, each with its own structure, despite a by and large shared confessional basis. A significant number of mainline Christians also belong to the Anglican Church of Southern Africa (about 5\%), the Lutheran Church in Southern Africa (about 3\%), Uniting 
Presbyterian Church in Southern Africa and the Baptist Union of Southern Africa (both about $2 \%)$. These churches were initially established as a result of missionary activities and remain connected to their erstwhile mother churches in Europe and the United States of America. They are also incorporated into transnational religious communities, such as the World Council of Churches (wcc), the World Methodist Council, the World Communion of Reformed Churches, the Anglican Communion or the Lutheran World Federation.

Another $40 \%$ of South African Christians, the second group, belong to African Independent/Initiated/Indigenous Churches (aics). In his seminal interpretation Harold Turner describes aics as churches that were founded "in Africa, by Africans, and primarily for Africans". ${ }^{44}$ This is an extremely diverse collection of churches, subject to numerous typologies. Much of Bengt Sundkler's initial typology of Ethiopian, Zionist and Messianic aics is still used, ${ }^{45}$ and there is consensus that aics, particularly their Ethiopian variants, started to develop in the late 1800 s to distance themselves from the mission churches and reclaim local beliefs and practices. ${ }^{46}$ By far the largest aic, and in fact the largest church, in South Africa is the Zion Christian Church (zcc), with $14 \%$ of Christians as its members. These churches have developed in ways that diverge radically from the development of mainline denominations in South Africa and remain relatively loosely connected to one another. They also remain removed from transnational religious communities. The establishment of the Organisation of African Instituted Churches (oaic) in 1978, following an invitation from Pope Shenouda iii of the Coptic Orthodox Church in Egypt, attempted to address this lack of coordination by creating a forum for aics leaders for "fellowship and to share their concerns" and "to provide better theological and biblical education" for the members of aics. ${ }^{47}$ The oaic is currently a member of the wcc and the All African Conference of Churches and engaged with the (then) World Alliance of Reformed Churches in a theological dialogue from 1998 to 2002 . $^{48}$ From the available documentation on the oaic, headquartered in Kenya, it seems that South African aics are not particularly active in the organisation. In the dialogue between the oaic and warc, for example, there were no representatives from South Africa in either of the teams.

A third group of South African Christians, about $10 \%$, belong to so-called Pentecostal and charismatic churches. The largest of these churches is the Apostolic Faith Mission. This group of churches is similar to the aics in the sense that its constituent churches have fairly loose sets of relationships amongst each other as well as to organisations outside South Africa. Even though these churches do not constitute a group in the sense that mainline churches, aics and Pentecostal and charismatic churches can be grouped together, the most reliable figures also identify about $9 \%$ of South African Christians who belong to "other" Christian denominations. This nebulous "group" will not form part of our reflection.

At this point it should be clear that there are some similarities as well as significant differences between the South African and German religious landscapes. In the following section we examine the ways in which churches actively structure their public engagement. Because of the dominance of the ekd and the Roman Catholic Church in Germany our discussion will be limited to the way that they structure their public engagement. The complexity of the South African situation will require a slightly longer and significantly more confusing account than the German situation. 


\section{Public Engagement}

In the previous section we showed that denominational affiliation in Germany is structured by and large according to membership of either the ekd or the Roman Catholic Church. The structure of denominational affiliation in South Africa is somewhat more complex, as no one denomination is in a position to act on behalf of a significant proportion of the Christians in the country. The differences in denominational affiliation are illustrated and amplified when one compares the concrete structures of public engagement established by churches in South Africa and Germany. For the sake of the comparison between South Africa and Germany we try to categorise the structures of public engagement in broadly three types. The first is structures of denominational churches and communities of churches. The second consists of ecumenical communities of churches, such as federations, networks, alliances, forums and the like. The third type covers networks, alliances, forums and consultations that go beyond specific Christian traditions and can therefore be called interreligious.

Applied to the South African situation some mainline denominations have structures by means of which denominations directly engage political actors via the South African Parliament. These structures of engagement are of the first type. Mainline churches draw on the financial and organisational strength provided by functioning as denominations and the legitimacy of speaking on behalf of a relatively large number of people. They often choose to engage audiences wider than their members either by means of public statements or offices dedicated to public engagement. The South African Catholic Bishops' Conference has arguably the most extensive structure in this regard. Its Parliamentary Liaison Office serves as the official link between the Catholic Church and the South African Parliament and government. ${ }^{49}$ It has twelve permanent employees, assisted by interns, who "contribute to debates on issues of public policy, exert an influence for the common good in areas of political, economic and social concern, and help shape legislative and policy developments" on behalf of the Catholic Church. Other mainline churches have similar, albeit much smaller, structures, such as the Parliamentary Desk of the Dutch Reformed Church. ${ }^{50}$ Individual Pentecostal and charismatic congregations do not have similar structures.

It is noteworthy that none of the aics, also not the zcc with more than five million members, have formal structures in place by means of which to engage political publics. This is a result of what seems like a general lack of structures aimed at representing aics in South Africa. An important exception is the Council of African Instituted Churches (caic). In 1995 ten aics came together to form the caic ${ }^{51}$ with the aim of "propagating the gospel of Jesus Christ by the African Independent Churches to the Black African masses". ${ }^{52}$ According to the wcc, the objectives of the caic are "creating fellowship, fostering theological education, promoting unity, and mutual assistance", and the Council seems to be directed at strengthening aics rather than providing a public interface. ${ }^{53}$ Even from the limited information available it is clear that the biggest aics are not members of the caic and it seems as if the caic does not have its own structures aimed at engaging political publics.

Focusing on the second and third type of structures of political engagement, it is not easy to navigate between the myriad of acronyms, allegiances and competing claims to legitimacy. In order to make sense of this, we shall approach the formation of these organisations in a 
broadly chronological manner. We start with structures of political engagement that are of the second type.

The fragmentation of the ecclesial landscape was first recognised by the organisers of the General Missionary Conference in 1904, who wanted to bring together South African Christians on "issues of common concern". ${ }^{54}$ Even though these missionary conferences and the resultant Christian Council of South Africa in 1936 are politically ambiguous, ${ }^{55}$ they constitute the first attempts at bringing together some of the many churches in South Africa. In 1968 the Christian Council changed its name to the South African Council of Churches (sacc), a body that played an important role in the struggle against the apartheid regime. It launched programmes to combat racism and "channelled resources from the world community to support the struggle [against apartheid]". ${ }^{56}$ The sacc has reframed its objectives in post-apartheid South Africa as the promotion of "the spiritual, social, intellectual and physical welfare of all people" by fostering church unity and acting on behalf of member churches. ${ }^{57}$ Its Parliamentary Office, amongst other initiatives and programmes, is one of the key instruments in this regard. ${ }^{58}$ During the struggle the sacc was often perceived as very close to the African National Congress (anc). With the establishment of its Parliamentary Office in 1996 it instituted the policy of "critical solidarity" towards the ancled government. ${ }^{59}$ In 2001 it changed the policy of critical solidarity to one of critical engagement. $^{60}$

The sacc has experienced a rather dramatic decline in public influence, or at least relevance, in post-apartheid South Africa. Its change in policy towards the government can be regarded as one of the explanations for its declining influence in post-apartheid South Africa. The sacc has become particularly critical of the presidency of Jacob Zuma. ${ }^{61}$ Many commentators, notably Ernst Conradie, ${ }^{62}$ recognise active attempts from the Zuma administration to marginalise the sacc. However, in addition to a political explanation, other reasons can also be given for the decline in their influence: funding related to the struggle against apartheid ceased, prominent church leaders were absorbed into the new democratic government and churches changed their focus to address challenges on denominational and congregational level. ${ }^{63}$ A further reason for the decline in its influence in post-apartheid South Africa is related to its relatively narrow membership. By and large only mainline denominations are members of the sacc, which makes it a body that is representative of far less than half of the Christians in South Africa.

In 1995 an umbrella organisation for some Pentecostal and charismatic churches in South Africa was also formed. The Evangelical Alliance of South Africa (teasa) came into existence after the predominantly white Evangelical Fellowship of South Africa merged with the predominantly black Concerned Evangelicals in $1995 .{ }^{64}$ Apart from the joint commitment to witness and fostering cooperation amongst churches in its fold, teasa addresses societal issues that are relevant to, or affect, evangelicals and Christians in general, and in particular aims at promoting "biblical values and ethics" in the formulation of public policy and "national life". ${ }^{65}$ Whereas alliances of evangelical Christians did not enjoy the same prominence as mainline denominations during the apartheid years-both those that supported and opposed apartheid-their perceived influence in post-apartheid South Africa expanded considerably. The membership of the sacc and teasa is, despite some exceptions, structured according to confessional proclivities. 
Interreligious groups with structures aimed at political engagement, type three, are intertwined with the second, but seem to be organised according to approach and even proximity to political actors. These organisations are interreligious, even though churchesand particularly church leaders - seem to play a prominent role. In this regard too, a chronological account will assist in untangling the different structures and their relations.

According to an often repeated narrative, Geraldine Fraser-Moleketi, Minister of Social Welfare in the Mandela administration, issued a challenge to South African religious communities to establish "a formal network of religious organizations" that would lead to "exchanges of best practice models, joint endeavours to improve the conditions of people through high-impact initiatives and resources sharing". According to Fraser-Moleketi, the South African government of the time needed such a network in order to "engage in a structured manner on a regular basis" with religious communities, including churches. ${ }^{66}$ Even though some narratives diverge at this point, one prominent narrative holds that an initiative by religious communities and an active role by Nelson Mandela led to the establishment of the National Religious Leaders Forum (nrlf) and the National Religious Association for Social Development (nrasd). The nrlf and nrasd are associated with one another on the basis of a Memorandum of Understanding. ${ }^{67}$

In 2005 the nrlf signed a Memorandum of Understanding with the Mbeki administration in which it agreed to engage the South African government in terms of five "aims". ${ }^{68}$ The agreement was to channel government funding to the religious sector, presumably via the nrasd, to further the principle of subsidiarity and in order for religious communities to implement "social programmes". The nrlf, on behalf of the religious sector, committed to implement social programmes in five "strategic areas", namely "early childhood development, social housing, social cohesion, skills development, and community- and home-based care" ${ }^{69}$

The function of the nrlf was perceived to be duplicated when Pastor Ray McCauley from the Rhema Bible Church, one of the largest charismatic churches in the country, established the National Interfaith Leaders Council (nilc) in 2009. According to some accounts, the nilc was ostensibly established with the support of President Jacob Zuma and at least partly in response to the critical stance of some members of the nrlf towards the Zuma administration. Churches represented by the nrlf and sacc, particularly the Catholic Church, reacted with surprise and a measure of shock. ${ }^{70}$ Some theorists, such as Kuperus, regard the establishment of nilc as a sign that the Rhema Bible Church was "potentially co-opted" by the Zuma administration. ${ }^{71}$ In 2010, according to some media releases, the nilc was supposed to have amalgamated with the nrlf to form the National Interfaith Council of South Africa (nicsa). In its congratulatory letter the anc describes nicsa as a response to Zuma's "call for the interfaith sector to partner with Government for the creation of an inclusive, cohesive and caring society" and congratulated McCauley and Archbishop Buti Tlhagale on their election as "interim co-chairmen". ${ }^{72}$ However, during November 2012 , more than a year later, the Presidency released a statement according to which Zuma met with McCauley, on behalf of the nrlf. ${ }^{73}$ According to the statement from Zuma's office, this meeting seemed to be on the launch of nicsa. 
Since the establishment of nilc, a further representative body was established under the auspices of the Ecumenical Foundation of Southern Africa, namely the National Church Leaders' Consultation (nclc). It includes representatives from the sacc and teasa, but not a broad range of aics. In a recent formulation it expresses its goal as seeking "a united ecumenical witness and action, in dealing with several of our national challenges". ${ }^{74}$ Three events in its relatively short history are of relevance for our discussion as they illustrate key differences between the nilc and the nclc. Firstly, in 2011 the nclc held a meeting during which it attempted to bridge some of the gaps between different churches and church groupings in South Africa. ${ }^{75}$ This meeting distinguished nclc from politically motivated or confessionally exclusive attempts at finding a unified vehicle for churches to engage political publics. Secondly, in 2012 nclc released a document sharply criticising the Zuma administration, and Zuma in particular. ${ }^{76}$ The anc Secretary General Gwede Mantashe responded by labelling it as "mischievous" and "vitriolic". ${ }^{77}$ Lastly, at a meeting early in 2013 members of the nclc alleged that nilc and nicsa are not legitimate vehicles for public and political engagement. In a letter signed by Tlhagale (officially the interim co-chairperson of nicsa) nclc requested consultation with its members before the launch of nicsa. ${ }^{78}$ However, according to the South African government's Department of Cooperative Governance and Traditional Affairs, nicsa was (finally) launched in June 2013. ${ }^{79}$ Mathole Motshekga, Chief Whip of the anc in Parliament from 2009-2013, is currently the Public Relations Secretary of nicsa. ${ }^{80}$

nicsa makes the claim that it represents "all faith-based organizations in South Africa". ${ }^{81}$ Based on the discussion above, this claim is difficult to believe. It has set itself six goals, namely to "restore the integrity of the family, rebuild a [sic] family unit, revive human values, deal with the triple challenges of poverty, unemployment and inequality, social cohesion, nation-building and the revival of the spirit of ubuntu" and to "participate and contribute in Africa and the world". ${ }^{82}$ The first three aims shows a close proximity to the themes and ways in which prominent evangelical churches engage in politics, whereas the fourth-especially by making use of official government terminology of "triple challenges" seems to be close to government policy.

The ways in which churches in Germany structure their public engagement, perhaps not surprisingly, diverge significantly from the approaches discussed above. Similarities, however, can be found with regard to type one engagements. The two German mainline churches structure their public engagement by means of liaison offices in the capital Berlin. Both the Roman Catholic Church and the ekd have offices that explore possibilities for and foster contact with the political institutions of the Federal State of Germany, such as the German parliament and the federal government. Both liaison offices were established very soon after the foundation of the Federal Republic of Germany.

The Catholic office was founded in 1950, about a year after the Protestants founded their representative body in late $1949 .{ }^{83}$ Until 1958 the ekd tried to foster its relationship with the government of the German Democratic Republic (gdr) by means of a special representative in East Berlin, Heinrich Grüber. He eventually lost his accreditation by the government in 1958 as a result of the increasing tension between German Protestant churches and the gdr government. ${ }^{84}$ In addition to the liaison office in Berlin a new department of the liaison office of the ekd was founded in Brussels in 1990. The aim of this 
office is to respond to the rising importance of the European Union for the legislature also on the national level. ${ }^{85}$

The Catholic Liaison Office in Berlin reports directly to the German Bishops' Conference and the Association of German Dioceses. Its mandate consists of "observing the development of the political and social spheres and the legislative initiatives of the Federal Government, supporting the preparation of bills and political decisions, making statements and executing the resolutions passed by the boards of the German Bishops' Conference." ${ }^{\prime 86}$ Apart from the representative himself, six other employees are engaged in specific political fields. ${ }^{87}$ In total, the office employs 16 persons, including administrative and management staff. The Catholic liaison office moved to Berlin in the year $2000^{88}$ and has started to represent the interests of the Catholic Church in Germany also on a European level. ${ }^{89}$

The permanent representative of the ekd at the Federal Government of Germany receives his mandate from the council of the ekd. This "diplomat" of the church ${ }^{90}$ fulfils a function similar to that of the head of the Catholic Liaison Office. The position is the interface between the church and the state on a national level. One the one hand, the representative informs the council of the ekd about current political agendas and developments; on the other hand, he represents the interest of the ekd vis-à-vis the German political institutions. ${ }^{91}$ The website of the representative of the ekd lists 19 positions, of which 10 are situated in Berlin and 9 are situated in the department in Brussels. ${ }^{92}$

Both liaison offices of the mainline churches stress the point of a trustful collaboration between the two offices. In a joint article Stephan Reimers and Karl Jüsten, in their respective functions as Protestant and Catholic representative at the Federal Government of Germany, argue that the work contains three dimensions: the first dimension entails social advocacy for marginalised people according to Proverbs $31: 8 .{ }^{93}$ The second dimension consists of the direct representation of the church's interests in the political sphere. ${ }^{94}$ This dimension takes into account that "there are only few fields [of politics] in which the churches do not directly or indirectly notice the possible effects of laws." 95 In both dimensions one can easily identify the core functions of the churches as interest groups, namely value orientation, moral claims and self-interest, which were referred to earlier. Reimers and Jüsten therefore convincingly sum up the task of the liaison offices in title of their article "Lobbying for God and the World". There is also a third dimension of the work, which exceeds the usual scope of lobbying in political systems and institutions. This dimension consists of the pastoral care that is offered and provided to all members of the political system, such as members and employees of Parliament, public office bearers, other lobbyists and (even) journalists. ${ }^{96}$

The structure of the ekd's Liaison Office mirrors that of the church federation's structure. The regional member churches of the ekd send their representatives to the parliaments and governments of the federal states and provinces in Germany. ${ }^{97}$ Therefore the Lutheran, Reformed and Unitarian federations amongst the umbrella of the ekd-namely the Vereinigte Evangelisch-Lutherische Kirche Deutschlands (velkd) [United Protestant-Lutheran Church in Germany], The Reformierte Bund in Deutschland [Reformed Union in Germany] and the Union Evangelischer Kirchen in der Evangelischen Kirche in Deutschland (uek) 
[Union of Protestant Churches in the Protestant Church in Germany] - do not maintain their own liaison offices at any kind of political institutions.

The same is true for the Orthodox churches in Germany and also for isolated Freikirchen in Germany. In fact, the German Orthodox churches established an Orthodox conference of Bishops only in 2010. The general secretary is situated in the city of Dortmund. Even though the Orthodox bishops have since then published a few documents on certain political question, e.g. on organ donation and transplantation, ${ }^{98}$ the structure of the conference does not include a representative at the state institutions in Berlin. According to the statutes, it is also not an explicit purpose of the bishops conference to maintain contact with political institutions. ${ }^{99}$

With regard to type two structures of political engagement, or ecumenical types of structures, many German Freikirchen are organised in the Vereinigung evangelischer Freikirchen (vef) [Association of Protestant Free Churches], which was founded in 1926. Members are, amongst others, the Mennonites, the Methodists and also Pentecostal churches in Germany. ${ }^{100}$ The vef can therefore be characterised as an ecumenical federation of churches of different denominations. Another organisation of Christian groups in Germany is the Evangelische Allianz in Deutschland (dea) [Evangelical Alliance in Germany]. This Alliance is not so much a federation of churches, but more an ecumenical and evangelical network of local Christian groups and individuals of different denominations that organises its collaboration in workshops and various subordinated and affiliated institutions and associations. ${ }^{101}$ The Alliance is closely linked to the German and international Lausanne Movement. $^{102}$

Following the example of the mainline churches, both the vef and the dea have started to delegate representatives to the German government in Berlin. Their offices were nonetheless established very recently compared to offices of the mainline churches - the vef office in 2000 and the office of the dea in 1999. ${ }^{103}$ The current delegate of the vef is a pastor in a Baptist congregation in Berlin, who fulfils the task of representative to the government as an honorary position. ${ }^{104}$ The representative of the dea has held a full-time position only since $2014 .{ }^{105}$ It is notable that neither the vef, its delegate, nor the dea and its delegate are mentioned on the website of the Federal Ministry of the Interior as being amongst the dialogue partners in Christian churches. ${ }^{106}$

There are a few other ecumenical structures established in Germany. The two representatives of the mainline churches at the federal parliament in Berlin express their close collaboration in the shared Presidency of the Gemeinsame Konferenz der Kirchen zur Entwicklungszusammenarbeit (gkke) [Joint Conference of Churches for Development Cooperation]. The Conference was founded in 1973 and is active in the political public sphere on topics of development cooperation and politics that affect the relations between the northern and southern hemisphere. ${ }^{107}$ Especially the yearly report on German weapon exports is a document broadly recognised in the political public sphere. ${ }^{108}$

Another broader ecumenical association is the Arbeitsgemeinschaft Christlicher Kirchen in Deutschland (ack) [Working Group of Christian Churches in Germany]. Its purpose is contained within the ecumenical idea itself: it aims to lead in real community and unity with 
Jesus Christ and amongst the churches and people on earth. ${ }^{109}$ Historically, the Working Group was founded after the Second World War shortly before the first Convention of the World Council of Churches was held in Amsterdam in 1948. The ack should represent the German post-war churches in the world-wide ecumenical movement. The ack has grown from five founder members to its current 17 full members, six visiting members and four ecumenical observers. ${ }^{110}$ The Members of the ack consist of a wide range of different Christian churches in Germany, such as Mennonites, Methodists and Baptists, several Orthodox churches, the two mainline churches and some side branches of the two mainline denominations in Germany, such as the Selbstständige Evangelisch-Lutherische Kirche [Independent Protestant-Lutheran Church]. ${ }^{111}$ Even though the representation of political concerns against political institutions is laid down in the statue in Art. 2.7, ${ }^{112}$ there are no specific structures in evidence that aim at exerting a particular political influence and claim in the German context apart from the board and the main office of the ack. ${ }^{113}$

According to the third type of structures in which churches can possibly make claims and communicate their interests in the political public, it is interesting to observe that there are no significant interreligious federations, alliances or boards are installed in the German case. The German Ministry of the Interior organises its dialogue with other-than-Christian religious partners and communities of faith according to the Christian example separately and individually for every religion. For example, the relation to the Jewish community in Germany was arranged in a contract between the state and the Zentralrat der Juden in Deutschland [Central Council of Jews in Germany]. This contract picks up the tradition of contracts between the state and Christian churches in Germany and is flanked by a number of regional contracts by the federal states with the Jewish communities in their respective region. ${ }^{114}$ Especially the dialogue with Islam has attracted attention in Germany in recent decades because of the rising fundamentalist Muslim movements also in Europe. Therefore the German government established the Deutsche Islam Konferenz (dik) [German Islam Conference] in 2006. Members of the dik are the nine biggest and most influential Muslim organisations in the country. ${ }^{115}$

\section{Intercontextuality?}

In this article we made use of research by the German theologian Wolfgang Huber and the South African theologian Dirk Smit to develop working definitions of the concepts of "church" and "public". The aim of the article was to contribute to a comparison between the public engagement of churches in South Africa and Germany. In order to keep within the scope of an article of this nature, we focused on the political dimensions of the "public" and on the concrete structures of what can be regarded as "church" in the respective societies. We conclude with a short discussion of similarities and differences, and some consequences for reflection on the practice of public theology.

Three similarities stand out. Firstly, the majority of South Africans and Germans belong to churches. Public engagement of church structures with some sort of political resonance thus seems to be a distinct possibility in both countries. The possibility for public engagement is strengthened, secondly, by what seems like the willingness of political actors to engage with churches. In South Africa, despite the increasing complexity of, and even distance in, the 
relationship between churches and the government, the establishment and remnants of the nrlf and nrasd, and even political attempts at reconfiguring the religious landscape, at least show that political actors view the engagement with churches as potentially important. In Germany political willingness to engage with and include the perspective of churches is evidenced by numerous activities. Apart from the general structures that were presented in this article, the state, for example, grants the mainline churches further access to many counselling and decision-making committees in important political fields such as media boards (so-called Rundfunkräte), Departments for Media Harmful to Young Persons (socalled Prüfstellen für jugendgefährdende Medien) and the National Council for Ethics (socalled Nationaler Ethikrat). ${ }^{116}$ Probably the most significant sign for the constitutional openness and willingness of the German state to engage with religious groups in general and the churches in special is the right to self-determined religious education in public schools granted in Art. 7.3 of the German Constitution. ${ }^{117}$ Many politicians themselves are members of the two mainline churches, and some of them are even active in Christian suborganisations of their respective parties, as evidenced by the Evangelische Arbeitskreis der cdu/csu (eak) [Protestant assembly of Christian in the cdu/csu]. ${ }^{118}$ It is clear, thirdly, that in both South Africa and Germany many churches are also willing to set up structures to engage with political publics. In Germany the ekd and in South Africa the Catholic Bishops Conference in particular have rather advanced structures in place such as, for example, the Catholic Parliamentary Liaison Office of the Southern African Catholic Bishops' Conference. We should note, however, that churches and Christian communities in general also find other structures and less structured initiatives to engage political actors. In South Africa and Germany individual church leaders also often play major roles in engaging political publics. A recent South African example is the attempt by the Pentecostal pastor Ray McCauley to broker a political deal between the governing African National Congress and the Economic Freedom Fighters, an opposition party. ${ }^{119}$ Overall, these and other similarities create a strong basis for exchange of experiences and theological perspectives on the public engagement of churches.

According to our analysis, four differences between the public engagement of churches in Germany and South Africa can also be identified. A first major difference is the extent to which Christians are represented by the established structures that engage in politics. In Germany the Catholic church and the ekd can credibly claim that their structures represent a significant number of the German population and the vast majority of Christians in Germany, even though it remains doubtful how many of the members of the two mainline churches would describe themselves as actively confessing Christians. In South Africa there is no ecumenical structure that can claim to represent the majority, or even a significant and representative number of Christians. This relates to a large extent to the near absence of representative structures amongst South African aics. A second, closely related difference is the make-up of the religious landscape. Whereas the German religious landscape is dominated by the historical and contemporary influence of the Protestant and Catholic churches, a very large number of different churches populate the South African religious landscape. Thirdly, and somewhat less tangibly, it would seem as if the ways in which South African churches engage in politics, and the ways in which the engagement is received, are much more fluid than the rather stable situation in Germany-despite all scenarios of a decline of religion in Germany. Not only the major changes that took place after the demise of the apartheid regime, but also what seems like shifting loyalties within churches and 
between churches and political actors, point toward a much more fluid situation in South Africa. Lastly, the political demand for, and therefore perceived need to create, interreligious structures in order to engage political actors and structures seems much more pronounced in South Africa than in Germany. There are no interreligious boards in Germany in which the churches must make their claims. In contrast to the situation in South Africa, the German state addresses not the religious field as such, but the religions separately.

In our view this comparison between the structure of public engagement of South African and German churches highlights two potential consequences for further reflection on contextuality in public theology. The first is the need for an awareness of the importance of, and difference between, the positions from which public theology is practised in the different contexts. Public theologians in South Africa engage with politics from positions within a fluid and plural ecclesial and religious landscape. In our view this multiplicity of Christian public engagements and often competing ecclesial and political alliances require different approaches from those required in stable ecclesial environments with officially recognised and established structures and close relations between state and mainline churches as in Germany. ${ }^{120}$ The second is the importance of, and differences in, ensuring the legitimacy of public engagement. Whereas German churches to some extent can rely on their representivity and historically established relationship to key political actors, South African churches have to rely on other sources as neither numbers nor history can ensure legitimacy. The resulting challenges for a critical voice from a public theologian differ in the different contexts of South African and German society. Because the public engagement of the German mainline churches is rather easily recognised by the political public, they are faced with questions about their proximity to political structures and the possibility this allows for critical engagement. The South African mainline churches face an opposite challenge: while they might easily raise critical claims and voices, they might also constantly question themselves as to how this voice in fact can be heard in the political public and not missed amidst the plurality of religious voices.

\section{NOTES}

${ }^{1}$ Dietrich Bonhoeffer Centre for Public Theology, "International Conference: Contextuality and Intercontextuality in Public Theology, 23-25 June 2011, University of Bamberg", <http://www.unibamberg.de/fileadmin/uni/fakultaeten/ppp_lehrstuehle/evangelische_theologie_1/pdf_Dateien/Flyer_Public_ Theology.pdf> [accessed 30 March 2015].

\footnotetext{
${ }^{2}$ Heinrich Bedford-Strohm, Florian Höhne, Tobias Reitmeier, eds, Contextuality and Intercontextuality in Public Theology. Proceedings from the Bamberg Conference 23.-25.06.2011 (Münster: lit Verlag, 2013).

${ }^{3}$ International Journal of Public Theology 8(4), 2014.

${ }^{4}$ International Journal of Public Theology 6(1), 2012.

5 Dominic O'Sullivan, "Reconciliation as Public Theology: Christian Thought in Comparative Indigenous Politics", International Journal of Public Theology 8:1 (2012), 5-24.

${ }^{6}$ J. Jayakiran Sebastian, "Engaging Multiculturalism as Public Theologians", International Journal of Public Theology, 8:3 (2014), 335-43.
} 
7 Mark G. Toulouse, "Two Nations under God: Religion and Public in Canada and the United States", International Journal of Public Theology, 8:3 (2014), 267-91.

${ }^{8}$ The Augsburg Confession, <http://bookofconcord.org/augsburgconfession.php> [accessed 30 March 2015], Article 8.

${ }^{9}$ Wolfgang Huber, Kirche (München: Kaiser Verlag, 1979), pp. 97-140.

${ }^{10}$ Wolfgang Huber, Folgen christlicher Freiheit: Ethik und Theorie der Kirche im Horizont der Barmer Theologischen Erklärung (Neukirchen-Vluyn: Neukirchener Verlag, 1983), p. 148. This quotation is a translation of the original German: "Der Ort, an dem der Kampf zwischen wahrer und falscher Kirche ausgetragen wird; der Ort also, an dem der Kampf um Entsprechung oder Verfehlung der wahren Kirche immer wieder von neuen ansteht".

${ }^{11}$ Dirk J. Smit, “Oor die Kerk as Unieke Samelewingsverband” [On the Church as a Unique Social Association]. Tydskrif vir die Geesteswetenskappe 36:2 (1996), 119-29, at 121-22.

${ }^{12}$ Smit, "Kerk as Unieke Samelewingsverband", 125. This quotation is a translation of the original Afrikaans: "Die Christelike geloofsgemeenskap is nie maar net die religieuse variant van natuurlike groepe, bewegings, sosiale strata en wat nog meer nie. Dit is hulle gemeenskaplike geloof in Christus wat Christene deel maak van die kerk, wat sy liggaam is."

${ }^{13}$ Huber, Folgen christlicher Freiheit, 169. This quotation is a translation of the original German: "Von der Sozialgestalt der Kirche kann nicht gesprochen werden, ohne daß zugleich von ihrem Wesen die Rede ist; von der erfahrenen Kirche kann nicht gesprochen werden, ohne daß zugleich von der geglaubten Kirche die Rede ist".

${ }^{14}$ Huber, Kirche, pp. 44-58.

${ }^{15}$ Jürgen Habermas, Strukturwandel der Öffentlichkeit: Untersuchungen zu einer Kategorie der bürgerlichen Gesellschaft (Neuwied: Luchterhand, 1962).

${ }^{16}$ Dirk J. Smit, "Notions of the Public and Doing Theology", International Journal of Public Theology 1 (2007), $431-54$, at 435.

${ }^{17}$ Wolfgang Huber, Kirche und Öffentlichkeit (München: Kaiser, 1973).

${ }^{18}$ Smit, "Notions of the Public", 432.

${ }^{19}$ Ibid., p. 433.

${ }^{20}$ Ibid., p. 437.

${ }^{21}$ Ibid., pp. 438-9.

${ }^{22}$ Ibid., p. 442.

${ }^{23}$ Wolfgang Huber, "Öffentliche Kirche in pluralen Öffentlichkeiten”, Evangelische Theologie 54:2 (1994), 15780.

${ }^{24}$ Huber, "Öffentliche Kirche", 159-62.

${ }^{25}$ Ibid., pp. 162-72. 
${ }^{26}$ Ibid., pp. $176-7$.

${ }^{27}$ Huber, Kirche und Öffentlichkeit, 28-9.

${ }^{28}$ Ibid., p. 2, pp. 632-45.

${ }^{29}$ Ulrich Willems, "Kirchen", in T. von Winter and U. Willems, eds. Interessenverbände in Deutschland (Wiesbaden: vs Verlag für Sozialwissenschaften, 2007), pp. 316-340 at p. 321. This citation is a translation from the original German: "spricht [. . .] viel dafür, die Kirchen mit Blick auf ihre Beteiligung am politischen Prozess als Interessenverbände (im weiteren Sinne) zu betrachten."

${ }^{30}$ Ibid., pp. 321-2.

${ }^{31}$ Statistics South Africa, "SA Primary", <http://www.statssa.gov.za/census01/html/RSAPrimary.pdf> [accessed 20 February 2015].

${ }^{32}$ Religious affiliation was not included in Census 2011 as Statistics South Africa found that users of the Census are not particularly interested in the religious affiliation of South Africans.

${ }^{33}$ A recent survey by the Pew Forum on Religion and Public life estimates that the number of Christians in South Africa in 2009 might even have increased to $87 \%$ of the total population. See PewResearchCenter Religion \& Public Life, "Sub-Saharan Africa Religion Database: South Africa", <http://www.pewforum.org/interactives/africa/country/203/> [accessed 30 March 2015]. Their sample, however, was relatively small (1504 persons) and the margin of error of the study is 5 points. For more on the methodology, see Pew Forum on Religion \& Public Life / Islam and Christianity in Sub-Saharan Africa, "Appendix C: Survey Methodology", <http://www.pewforum.org/files/2010/04/sub-saharan-africa-appendix-c.pdf> [accessed on 30 March 2015].

${ }^{34}$ Statistische Bundesamt, "Zensus 2011", <https://www.destatis.de/DE/PresseService/Presse/Pressekonferenzen/2013/Zensus2011/bevoelkerung_zens us2011.pdf?_blob=publicationFile> [accessed 30 March 2015].

${ }^{35}$ Evangelische Kirche in Deutschland, "Statistik über die Äußerungen des kirchlichen Lebens in den Bundesländern im Jahr" <http://www.ekd.de/download/kirch_leben_2010_bundeslaender.pdf> [accessed 30 March 2015].

${ }^{36}$ For further reading: Karl Gabriel, ed., Religiöse Individualisierung oder Säkularisierung: Biographie und Gruppe als Bezugspunkte moderner Religiosität (Gütersloh: Gütersloher Verlagshaus, 1996). Also: Rolf Schieder, Sind Religionen gefährlich? Religionspolitische Perspektiven für das 21. Jahrhundert, 2nd edn. (Berlin: Berlin University Press, 2011), pp. 206-14.

${ }^{37}$ Evangelische Kirche in Deutschland, "Zahlen und Fakten zum kirchlichen Leben 2004", <http://www.ekd.de/download/broschuere_2004_internet.pdf> [accessed 30 March 2015]; Evangelische Kirche in Deutschland, "Zahlen und Fakten zum kirchlichen Leben 2014", <http://www.ekd.de/download/zahlen_und_fakten_2014.pdf> [accessed 30 March 2015].

${ }^{38}$ Evangelische Kirche in Deutschland, "Engagement und Indifferenz: Kirchenmitgliedschaft als soziale Praxis", <http://www.ekd.de/download/ekd_v_kmu2014.pdf> [accessed 30 March 2015], 15.

39 Evangelische Kirche in Deutschland, "1.1 Grundordnung EKD (GO-EKD)", <http://www.kirchenrechtekd.de/showdocument/id/3435\#s1.100004> [accessed 30 March 2015], Article 1. This quotation is a translation of the original German: "Die Evangelische Kirche in Deutschland ist die Gemeinschaft ihrer lutherischen, reformierten und unierten Gliedkirchen."

${ }^{40}$ Ibid. 
${ }^{41}$ Hermann Barth and Christoph Thiele, "Evangelische Kirche in Deutschland", in W. Heun, M. Honecker, M. Morlok, J. Wieland, eds, Evangelisches Staatslexikon (Stuttgart: Kohlhammer, 2006), pp. 525-36, at p. 530. This quotation is a translation of the original German: "Maßnahmen, durch welche die EKD erst Kirche werden müsste, sind nicht mehr nötig. Sie ist es im theologischen Sinne schon, denn Kirchengemeinschaft ist Kirche."

${ }^{42}$ See e.g. Hans Michael Heinig, “Die Stellung der Kirchen im rechtlichen Gefüge der Bundesrepublik Deutschland”, in G. Frank, V. Leppin, Th. Seidel, eds, Staat, Religion, Bildung: Reformatorisches Erbe vor den Herausforderungen einer säkularen Gesellschaft. Beiträge zum 2. Thüringer Melachthon-Tag am 19. und 20. Februar 2010 im Thüringer Landtag (Weimar and Eisenach: Wartburg Verlag, 2011), pp. 88-99.

${ }^{43}$ Erich Geldbach, "Freikirchen; in Heun, Honecker, Morlok and Wieland", eds, Evangelisches Staatslexikon, pp. 655-61.

${ }^{44}$ H. W. Turner, "A Typology for African Religious Movements", Journal of Religion in Africa, 1 (1967), 1-34, at 17.

${ }^{45}$ G. M. Sundkler, Bantu Prophets in South Africa, 2nd ed. (London: Oxford University Press, 1961[1948]).

${ }^{46}$ See e.g. Hennie Pretorius and Lizo Jafta, “'A Branch Springs Out': African Initiated Churches”, in Richard Elphick and Rodney Davenport, eds, Christianity in South Africa: A Political, Social and Cultural History (Berkeley, ca: University of California Press, 1997), pp. 211-226.

${ }^{47}$ Masilo Molobi, "The Ecumenical Vision of the Organization of African Independent Churches from an Educational Perspective", Studia Historiae Ecclesiasticae xxxvii:1 (2011), 87-102. The online pdf version of this article is available at http://uir.unisa.ac.za/bitstream/handle/10500/4634/Molobi.pdf?sequence=1\&isAllowed=y and it not paginated. This reference is from p. 4 of the online version.

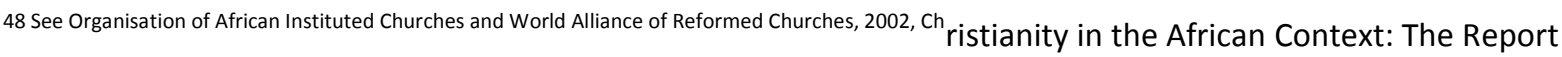
of the International Theological Dialogue between the Organization of African Instituted Churches and the World Alliance of Reformed Churches (1998-2002), <http://www.ecumenism.net/archive/docu/2002_aic_warc_report.pdf> [accessed 30 March 2015].

${ }^{49}$ Southern African Catholic Bishops' Conference Parliamentary Liaison Office, "Catholic Parliamentary Liaison Office", <http://www.cplo.org.za> [accessed 30 March 2015].

${ }^{50}$ Nederduitse Gereformeerde Kerk in Suid-Afrika, "Sinodale begroting en werksaamhede", <http://www.kaapkerk.co.za/wp/wp-content/uploads/2013/03/2013-11-07_Sinodale-Werksaamhede.doc> [accessed 30 March 2015], pp. 17-8.

${ }^{51}$ Barbara Bompani, "African Independent Churches in Post-Apartheid South Africa: New Political Interpretations", Journal of Southern African Studies 34:3 (2008), 665-77, at 671.

52 World Council of Churches, "Council of African Instituted Churches", <http://www.oikoumene.org/en/member-churches/council-of-african-instituted-churches> [accessed 30 March 2015].

${ }^{53}$ Ibid.

${ }^{54}$ South African Council of Churches, "History of SACC", <http://www.sacc.org.za/pages/history.html> [accessed 30 March 2015].

55 David Thomas, "The Christian Council of South Africa as a platform for assimilationist racial ideology", Journal of Theology for Southern Africa 67 (1989), 24-36. 
${ }^{56}$ Raymond Simangaliso Kumalo, "Christianity and Political Engagement in Post-Apartheid South Africa", Political Theology 15:3 (2014), 220-30, at 227.

${ }^{57}$ South African Council of Churches, "SACC Governance", $<$ http://www.sacc.org.za/pages/governance.html\#member> [accessed 30 March 2015].

${ }^{58}$ South African Council of Churches Parliamentary Office, "SACC Parliamentary Office Homepage", $<$ http://www.sacc-ct.org.za/> [accessed 30 March 2015].

${ }^{59}$ South African Council of Churches, "National Head Office", <http://www.sacc.org.za/pages/national.html> [accessed 30 March 2015].

${ }^{60}$ See Raymond Simangaliso Kumalo, "Facts and Faction [Fiction?]: The Development of Church and State Relations in Democratic South Africa from 1994-2012", Journal of Church and State 56:4 (2014), 627-43.

${ }^{61}$ See e.g. Qaanitah Hunter and Mmanaledi Mataboge, "Why churches dumped the ANC", Mail \& Guardian (23 December 2014), <http://mg.co.za/article/2014-12-22-why-churches-dumped-the-anc> [accessed 30 March 2015]; Mandy de Waal, "ANC's conflict with the South African Council of Churches: The Origin", Daily Maverick (13 December 2012), $<$ www.dailymaverick.co.za/article/2012-12-13-ancs-conflict-with-the-south-african-council-of-churches-theorigin> [accessed 30 March 2015]; Cape Argus, "Top Clerics Pen Letter to Zuma", iol News (12 December 2012), <http://www.iol.co.za/news/top-clerics-pen-letter-to-zuma-1.1439546\#.VRkmK5OUe5L> [accessed 30 March 2015].

${ }^{62}$ Ernst Conradie, "Notions and Forms of Ecumenicity: Some South African Perspectives", in Ernst M. Conradie, ed., South African Perspectives on Notions and Forms of Ecumenicity (Stellenbosch: sun press, 2013), pp. 1322.

${ }^{63}$ Kumalo, "Christianity and Political Engagement", 227.

${ }^{64}$ The Evangelical Alliance of South Africa, "About Us", <http://www.teasa.org.za/about-us/> [accessed 30 March 2015].

${ }^{65}$ The Evangelical Alliance of South Africa, "The Constitution of the Evangelical Alliance of South Africa", <http://www.teasa.org.za/wp-content/uploads/2013/11/TEASA-Constitution.pdf> [accessed 30 March 2015].

${ }^{66}$ See Kumalo, "Facts and Fiction" [Faction in fn 60?], and National Religious Association for Social Development, "History", <http://www.nrasd.org.za/about/> [accessed 30 March 2015].

${ }^{67}$ Conradie, "Notions and Forms of Ecumenicity", in Conradie, ed, South African Perspectives on Notions and Forms of Ecumenicity, p. 14.

${ }^{68}$ Ignatius Swart, "Churches and the Rising Expectations in Social Welfare Delivery: South Africa in an International Comparative Perspective", in Wilhelm Gräb and Lars Charbonnier, eds, The Impact of Religion on Social Cohesion, Social Capital Formation and Social Development in Different Cultural Contexts (Münster: lit Verlag, 2014), pp. 73-92.

${ }^{69}$ Swart, "Churches and the Rising Expectations", in Gräb and Charbonnier, eds, The Impact of Religion on Social Cohesion, Social Capital Formation and Social Development in Different Cultural Contexts, p. 77.

${ }^{70}$ http://www.catholicnews.com/data/stories/cns/0903826.htm.

${ }^{71}$ Tracy Kuperus, "The Political Role and Democratic Contribution of Churches in Post-Apartheid South Africa", Journal of Church and State 53:2 (2011), 278-306, at 295-9. 
${ }^{72}$ African National Congress Parliamentary Caucus, "New National Interfaith Body" (5 September 2010), $<$ http://www.anc.org.za/caucus/show.php?ID=2242> [accessed 30 March 2015].

${ }^{73}$ Conradie, "Notions and Forms of Ecumenicity", in Conradie, ed., South African Perspectives on Notions and Forms of Ecumenicity, p. 15; The Presidency, Republic of South Africa, "President Zuma Meets with Religious Leaders" (28 November 2012), <http://www.presidency.gov.za/pebble.asp?relid=7358> [accessed 30 March 2015].

${ }^{74}$ The Methodist Church of Southern Africa, "National Church Leaders' Consultation Statement" (16 October 2013), <http://www.methodist.org.za/news/10172013-0922> [accessed 30 March 2015].

75 Ecumenical Foundation of Southern Africa, “Historic Church Leaders' Meeting for South Africa" (17 November 2011),

<http://www.efsa-institute.org.za/2011/11/historic-church-leaders'-meeting-for-south-africa/> [accessed 30 March 2015].

${ }^{76}$ South African Council of Churches, The Evangelical Alliance of South Africa, Kairos sa and African Enterprise, "The church speaks ... for such a time as this ..." (25 November 2012), <http://www.sacc.org.za/content/SACC\%202012\%20DOCS/DEC\%202012/The\%20church\%20speaks\%20_Final \%20\%2030\%2011\%202012.pdf> [accessed 30 March 2015].

${ }^{77}$ Sam Mkokeli, “Mantashe Warns Bishops to Back Off”, Business Day (12 December 2012), <http://www.bdlive.co.za/national/politics/2012/12/12/mantashe-warns-bishops-to-back-off> [accessed 30 March 2015].

${ }^{78}$ Conradie, "Notions and Forms of Ecumenicity", in Conradie, ed., South African Perspectives on Notions and Forms of Ecumenicity, p. 15.

${ }^{79}$ Department of Cooperative Governance and Traditional Affairs, "Department of Cooperative Launches the National Interfaith Council of South Africa", <http://www.cogta.gov.za/index.php/news/latest/428-department-of-cooperative-governance-launches-thenational-interfaith-council-of-south-africa> [accessed 20 February 2015].

${ }^{80}$ This is according to his self-description at an event at which he delivered a speech shortly after the death of Nelson Mandela. Mathole Motshekga, “Opening remarks at the Nelson Rolihlahla Mandela Interfaith Memorial Service hosted by the University of South Africa (UNISA)", <http://www.unisa.ac.za/news/wp-content/uploads/2013/12/The-Nelson-Rolihlahla-Mandela-11-Dec2013.pdf> [accessed 30 March 2015].

${ }^{81}$ National Interfaith Council of South Africa, "About National Interfaith Council of South Africa", <http://www.nicsa.org.za/aboutus.htm> [accessed 30 March 2015].

82 Ibid.

${ }^{83}$ Deutsche Bischofskonferenz, "Katholische Büro in Berlin", <http://www.dbk.de/ueber-uns/katholisches-buero-berlin> [accessed 30 March 2015]; Evangelische Kirche in Deutschland, "Der Bevollmächtigte des Rates der EKD: Dienststelle Brüssel”, <http://www.ekd.de/bevollmaechtigter/bruessel.html> [accessed 30 March 2015].

${ }^{84}$ Hermann E. J. Kalinna: “Verbindungsstellen zwischen Staat und Kirchen”, in: J. Listl and D. Pirson, eds., Handbuch des Staatskirchenrechts der Bundesrepublik Deutschland, Vol 2, 2nd edn (Berlin: Duncker\&Humblot, 1995), pp. 181-195. at pp. 182-3.

${ }^{85}$ Evangelische Kirche in Deutschland, "EKD Office Brussels", <http://www.ekd.de/english/eu_office_brussels.html> [accessed 30 March 2015]. 
${ }^{86}$ Deutsche Bischofskonferenz, "Catholic Liaison Office in Berlin", $<$ http://www.dbk.de/en/ueber-uns/katholisches-buero-berlin/> [accessed 30 March 2015].

${ }^{87}$ Kommissariat der Deutscen Bischöfe, "Aufgaben und Mitarbeiter", http://www.kath-buero.de/index.php/organisation.html [accessed 30 March 2015].

${ }^{88}$ Kommissariat der Deutschen Bischöfe, "Geschichte des Hauses", $<$ http://www.kath-buero.de/index.php/geschichte-des-hauses.html> [accessed 30 March 2015].

${ }^{89}$ Kommissariat der Deutschen Bischöfe, "Katholisches Büro", <http://www.kath-buero.de/index.php/start.html> [accessed 30 March 2015].

${ }^{90}$ Stephan Reimers, "Tu Deinen Mund auf für die Stummen . . Aufgaben des Bevollmächtigten des Rates der EKD in Berlin und Brüssel", Zeitschrift für Evangelische Ethik, 47 (2003), 93-299. at 295.

${ }^{91}$ Evangelische Kirche in Deutschland, "Der Bevollmächtigte des Rates der EKD", <http://www.ekd.de/bevollmaechtigter/index.html> [accessed 30 March 2015].

${ }^{92}$ Evangelische Kirche in Deutschland, "Dienstelle Berlin", <http://www.ekd.de/bevollmaechtigter/referate_berlin.html> [accessed 30 March 2015]; Evangelische Kirche in Deutschland, "Dienstelle Brüssel", <http://www.ekd.de/bevollmaechtigter/bruessel/referate_bruessel.html> [accessed 30 March 2015].

${ }^{93}$ Stephan Reimers and Karl Jüsten, "Lobbying' for God and the world", in S. Schmidt and M. Wedell, eds., "Um der Freiheit willen ..." Kirche und Staat im 21. Jahrhundert. Festschrift für Buckhard Reichert. (Freiburg: Herder, 2002), pp. 221-31. at. p. 227-8.

${ }^{94}$ Ibid., pp. 228-9.

${ }^{95}$ Ibid., p. 228. This is a translation of the original German: "Es gibt nur weniger Arbeitsfelder, wo die Kirchen nicht direkt oder indirekt Auswirkungen von Gesetzen spüren."

${ }^{96}$ Ibid., pp. 229-30.

${ }^{97}$ Kalinna, "Verbindungsstellen zwischen Staat und Kirchen", in Listl and Pirson, eds, Handbuch des Staatskirchenrechts der Bundesrepublik Deutschland, Vol. 2, p. 182.

${ }^{98}$ Orthodoxe Bischofskonferenz in Deutschland, "Organspende und -transplantation Stellungnahme der Orthodoxen Bischofskonferenz in Deutschland (OBKD)", <http://www.obkd.de/Texte/OrganspendeundTransplantation.pdf> [accessed 30 March 2015].

${ }^{99}$ Orthodoxe Bischofskonferenz in Deutschland, "Satzung der Orthodoxen Bischofskonferenz in Deutschland", <http://www.obkd.de/Texte/OBKD\%20-\%20Satzung.pdf> [accessed 30 March 2015].

${ }^{100}$ Vereinigung Evangelischer Freikirchen, “Wer wir sind”, <http://www.vef.de/wer-wir-sind/> [accessed 30 March 2015].

${ }^{101}$ Die Evangelische Allianz in Deutschland, "Die Evangelische Allianz als Netzwerk", $<$ http://www.ead.de/die-allianz/netzwerk/die-evangelische-allianz-als-netzwerk.html> [accessed 30 March 2015].

${ }^{102}$ Katja Guske, Zwischen Bibel und Grundgesetz. Die Religionspolitik der Evangelikalen in Deutschland (Wiesbaden: Springer Verlag, 2014), at p. 75. 
${ }^{104}$ Vereinigung Evangelischer Freikirchen, "Beauftragter am Sitz der Bundesregierung", $<$ http://www.vef.de/vorstand-beauftragte/beauftragter-am-sitz-der-bundesregierung/> [accessed 30 March 2015].

${ }^{105}$ Die Evangelische Allianz in Deutschland, "Beauftragter der DEA", $<$ <ttp://www.ead.de/arbeitskreise/politik/beauftragter-der-dea.html> [accessed 30 March 2015].

${ }^{106}$ Bundesministerium des Inneren, "Christliche Kirche", $<$ http://www.bmi.bund.de/DE/Themen/Gesellschaft-Verfassung/Staat-Religion/Christliche-Kirchen/christlichekirchen_node.html> [accessed 30 March 2015].

${ }^{107}$ Gemeinsame Konferenz Kirche und Entwicklung, "GKKE: Home”, <http://www3.gkke.org/> [accessed 30 March 2015].

${ }^{108}$ Reimers and Jüsten, "'Lobbying' for God and the world", in: Schmidt and Wedell, eds, "Um der Freiheit willen ..." Kirche und Staat im 21. Jahrhundert. Festschrift für Buckhard Reichert, p. 227.

${ }^{109}$ Arbeitsgemeinschaft Christlicher Kirchen in Deutschland, "Die Arbeitsgemeinschaft Christlicher Kirchen", $<$ http://www.oekumene-ack.de/ueber-uns/> [accessed 30 March 2015].

${ }^{110}$ Arbeitsgemeinschaft Christlicher Kirchen in Deutschland, "Geschichte der ACK", <http://www.oekumene-ack.de/ueber-uns/geschichte/> [accessed 30 March 2015].

${ }^{111}$ Arbeitsgemeinschaft Christlicher Kirchen in Deutschland, "Mitglieder", <http://www.oekumene-ack.de/ueber-uns/mitglieder/> [accessed 30 March 2015].

${ }^{112}$ Arbeitsgemeinschaft Christlicher Kirchen in Deutschland, "Satzung der Arbeitsgemeinschaft Christlicher Kirchen in Deutschland", <http://www.oekumene-ack.de/fileadmin/user_upload/Grundlagen_der_Zusammenarbeit/Satzung_ACK.pdf> [accessed 30 March 2015].

${ }^{113}$ Arbeitsgemeinschaft Christlicher Kirchen in Deutschland, "Struktur der ACK", $<$ http://www.oekumene-ack.de/ueber-uns/struktur/> [accessed 30 March 2015].

${ }^{114}$ Bundesministerium des Inneren, "Verträge mit der jüdischen Gemeinschaft", $<$ http://www.bmi.bund.de/DE/Themen/Gesellschaft-Verfassung/Staat-Religion/JuedischeGemeinschaft/Vertraege-juedischenGemeinschaft/vertraege-juedischengemeinschaft_node.html> [accessed 30 March 2015].

${ }^{115}$ Bundesministerium des Inneren, "Deutsche Islam Konferenz", $<$ http://www.bmi.bund.de/DE/Themen/Gesellschaft-Verfassung/Deutsche-Islam-Konferenz/deutsche-islamkonferenz_node.html> [accessed 30 March 2015].

${ }^{116}$ Willems, "Kirchen", in von Winter and Willems, eds, Interessenverbände in Deutschland, pp. 330-1.

${ }^{117}$ Arnulf von Scheliha, "Kirche und Staat: Staatskirchenrecht / Religionsrecht / Religion und Politik / Religionsfreiheit", in Wilhelm Gräb and Birgit Weyel, eds, Handbuch Praktische Theologie (Gütersloh: Gütersloher Verlagshaus, 2007), pp. 101-12, at p. 103.

${ }^{118}$ Willems, “Kirchen”, in von Winter and Willems, eds, Interessenverbände in Deutschland, p. 330. 
${ }^{119}$ See e.g. Stephen Grootes, "McCauley brokering ANC, EFF peace deal ahead of SONA", (10 February 2015) Eyewitness News,

<http://ewn.co.za/2015/02/10/Ray-McCauley-brokering-peace-deal-with-EFF-ahead-of-Sona> [accessed 30 March 2015].

${ }^{120}$ The political scientist Ulrich Willems provocatively argues that the actual influence of the German mainline churches is rather limited if one takes their general strength in members, structures and finances into account. Willems, "Kirchen", in von Winter and Willems, eds, Interessenverbände in Deutschland, p. 327. 